\title{
Infectious and Radioactive Waste Management in a Diagnostic and Nuclear Medicine Centre
}

\author{
Tauqir Nasir ${ }^{1}$, Shafaqat Ali ${ }^{1, *}$, Mujahid Farid ${ }^{2}$, Muhammad Shahbaz ${ }^{3}$, Muhammad Rizwan ${ }^{1}$, \\ Fakhir Hannan ${ }^{1}$, Rehan Ahmad ${ }^{1}$
}

${ }^{1}$ Department of Environmental Sciences and Engineering, Government College University, Faisalabad, Pakistan

${ }^{2}$ Department of Environmental Sciences, University of Gujrat, Hafiz Hayat Campus, Gujrat, Pakistan

${ }^{3}$ Punjab Institute of Nuclear Medicine (PINUM) Hospital, Faisalabad, Pakistan

Email address:

shafaqataligill@yahoo.com (S. Ali),mujahid726@yahoo.com (M. Farid)

\section{To cite this article:}

Tauqir Nasir, Shafaqat Ali, Mujahid Farid, Muhammad Shahbaz, Muhammad Rizwan, Fakhir Hannan, Rehan Ahmad. Infectious and Radioactive Waste Management in a Diagnostic and Nuclear Medicine Centre. American Journal of Environmental Protection.

Vol. 4, No. 5, 2015, pp. 245-250. doi: 10.11648/j.ajep.20150405.15

\begin{abstract}
Hospital and medical waste management practices are very unsatisfactory in developing countries especially in Pakistan. Existing techniques and practices are not in accordance with the guidelines and levels prescribed by the WHO (World Health Organization) and other international bodies concerned with environment and human health. The objective of this study was to design and implement a proper waste management plan for the PINUM (Punjab institute of Nuclear Medicine) hospital Faisalabad, Pakistan. At PINUM Hospital infectious waste is produced as a result of diagnostic and radioactive waste as a result of diagnostic and therapeutic activities in nuclear medicine. This study was carried out in a period of 10 months in two phases. In first phase a proper infectious waste management plan was designed and incorporated at hospital and in 2nd phase proper management plan for radioactive waste was designed and implemented. Results showed a $43 \%$ reduction in volume and treatment cost of infectious waste resulting from proper management. There was significant decrease in prescribed storage time of radioactive waste which is done to bring its activity to normal level. It was evident from the results if radioactive waste properly segregated, lose radioactive waste (gloves, swabs, absorbing sheets, tissue papers etc.) can be disposed off much earlier than the compact radioactive waste (radioactive vials, needles and sharps).
\end{abstract}

Keywords: Hospital, Infectious, Radioactive, Nuclear, Medicine

\section{Introduction}

Throughout the world the problem of health and environment is a debatable issue. One of the major environmental problems is the poor hospital waste management, which may significantly increase the exposure of infectious pollutants [1]. Hospital produce a tremendous amount of medical waste, has increased greatly because of the use of more disposable items, such as syringes, gloves, glass and plastic vials, blood bags etc [2].

Medical waste is defined as any solid or liquid waste that is generated from treatment of human beings in a hospital or clinic, from clinical diagnosis, treatment and pathological testing and from medical research and have ability to cause infectious disease $[3,4]$. Improper management of health care waste results in transmission of infectious diseases like neurological disorders; typhoid, cholera, HIV and Hepatitis (B and C), cancer, asthma and mutagenicity [5, 6, 7, 8, 9]. It also pollutes water, air and soil, produce foul odor and enhance production and growth of insects, worms, and rodents $[10,11]$. $75-90 \%$ of the waste produced by the health care facilities is general or ordinary waste in nature [10].

Present study was carried out at PINUM (Punjab institute of nuclear medicine) cancer hospital Faisalabad. It is providing diagnostic and therapeutic services in nuclear medicine and general medical procedures in the town. Different radioisotopes are being used for diagnosis and treatment of patients. Numbers of unsealed radioisotopes are being used at PINUM e.g. $99 \mathrm{mTc}$, I-131.Proper management plan for the waste produced by PINUM hospital was developed which includes waste segregation, collection, transportation, storage, disposal and waste minimization and reuse [12]. Protocols and SOPs (Standard Operating Procedures) were designed for infectious and radioactive waste management. Infectious 
waste is mainly produced by the Clinical, PCR and RIA laboratories and their sample collection rooms. It includes syringes; sample collection tubes, swabs, used tissue papers, blood and serum samples of Hepatitis C (HCV), Hepatitis B (HBV), and TB and other infectious diseases.

Annually approximately 40 thousand investigations are done by these labs collectively and a large amount of them includes infectious diseases like HBV, HCV and TB. Medical waste is considered as subcategory of hospital waste that contains both infectious and ordinary waste. Infectious waste contains pathogens of infectious diseases and can cause infectious diseases to humans $[13,14]$.The main objective of safe disposal of radioactive waste is to ensure that the radiation exposure does not exceed the prescribed safe limits for public, radiation workers and environment [15].

\section{Materials and Methods}

\subsection{Phase 1}

Development and implementation of protocols for proper and effective management of infectious waste produced at PINUM hospital. Infectious waste is generated as the result of diagnostic facilities provided for diseases such as PCR for HCV, HBV, Tuberculosis, and Fungal keratatits, other Clinical procedures and radioimmunology assay. Infectious waste contains syringes, swabs, gloves, and tissue papers etc. which are used to collect blood samples. Infectious waste also contains blood, Blood serum and other body tissues of humans. Infectious waste generated was segregated properly at the point of generation. Peddle baskets (purchased from local market) for infectious and non-infectious waste and were properly labeled with tags, covered from inside with polythene bags to avoid any kind of spillage of liquid waste materials. Waste was segregated at the point of generation by the staff in respective baskets. Stored according to the guidelines and finally transported and treated at disposal site. Staff and waste handlers were educated and awareness was created about the proper and improper waste management and ultimately its consequences on human and environmental health.

In this study to check the presence of Hepatitis B and C virus in the residual ash from incinerator conventional PCR was performed. For this purpose serum of positive samples for $\mathrm{HCV}$ and HBV (as Controls) and Ultra-pure water was mixed with ash and PCR was done.

\subsubsection{Infectious Waste Incineration}

Infectious waste was stored at an isolated area in closed containers and then incinerated on weekly basis in controlled and according to WHO guidelines designed incinerator (INCINER8 Company)

\subsubsection{Nucleic Acids Extraction}

DNA and RNA were extracted by using GF-1 kit obtained from Vivantis, chemicals and reagents were provided with kit and extraction was done according to the protocol provided with extraction kit.

\subsubsection{Nested PCR}

Nested PCR was performed (Eppendorf thermal cycler gradient machine) for both $\mathrm{HCV}$ and $\mathrm{HBV}$ positive blood serum mixed ash and Ultra-pure water mixed ash samples. Primers used for HCV Round 1 Forward primer (S1 5' GCCATGGCGTTAGTATGAGT-3'), Reverse primer (AS1 5-'GTGCACGGTCTACGAGACCT-3') Round 2 Forward primer (S2 5'-GTGCAGCCTCCAGGACCC-3) Reverse primer (AS 25'-CCGTGAGCGTTCGTGGGATA-3') and primers used for $\mathrm{HBV}$ were Forward primer (CGGCATATGGAGAACATCACATCAG) Reverse primer (CACCTCGAGTTAAATGTATACCCAAAG). 50 bp marker used for $\mathrm{HCV}$ while $100 \mathrm{bp}$ was used for HBV provided by Fermentas.

\subsection{Phase 2}

Development and implementation of protocols and practices for proper and effective management of radioactive waste under the guidelines of PNRA (Pakistan nuclear regulatory authority).

Radioactive waste at PINUM hospital is comprised of used vials, syringes, swabs, gloves contaminated with $99 \mathrm{mTc}$, I-131. Waste was segregated at the point of generation in polythene bags into two categories one containing sharps such as syringes, vials and second containing contaminated gloves, swabs, and tissue papers. Radioactive waste was stored in closed containers in isolated waste store room according to their half-lives for the period of 3 to 6 months to bring the activity to background level. Containers and baskets were labeled as "RADIOACTIVE WASTE". On the disposal date activity of waste was again measured with the help of digital survey meter. Check sheets and house keeping records were maintained and waste was sent for incineration and then final disposal in closed containers, before final disposal activity from radioactive waste was again measured. Radioactive waste was disposed off according to the guidelines of PNRA (Pakistan Nuclear Regulatory Authority) and IAEA.

\subsection{Materials Used}

\subsubsection{Radiation Survey Meter}

Survey Meter for Radiation Detection (DSM-506 by G-M and scintillation) was used to detect and quantify the radiations at the place of radioactive waste storage and at the time of disposal.

\subsubsection{Others}

1. Lead made peddle baskets were used for segregated radioactive waste at the point of generation before sending it to storage room.

2. Absorbing sheets used during preparation of radioactive element dose for patients to absorb the liquid dose in case of spillage.

3. Radioactive waste trolley (locally manufactured) made up of lead was used to transport the radioactive waste easily and safely.

4. Dose calibrator (Atomlab ${ }^{\text {TM }} 500$ Plus) used to calibrate the dose of radioactive substance before administering to patients. 


\section{Results}

\subsection{Infectious Waste}

Approximately $50 \mathrm{~kg}$ of waste was being produced daily from diagnostic labs (Clinical, PCR and RIA), general medical procedures, and chemotherapy for cancer patients, ordinary waste from cafeteria and office work etc. As a result of this research project, waste management plan was implemented at hospital which includes proper segregation of waste, storage, transport, treatment and final disposal. Consequently volume of infectious waste recorded to be $28 \mathrm{~kg}$ and ordinary waste was $21 \mathrm{~kg}$ approximately. Ordinary waste can be disposed off together with municipal waste without any prior treatment which means that there was $43 \%$ reduction in infectious waste treatment cost and its volume due to proper segregation of waste at its point of generation. Cost on treatment of waste (incineration cost) and emissions, residual ash from incinerator was also decreased remarkably.

\subsection{PCR Results for Hepatitis C}

Ash of incinerated infectious waste was mixed with blood serum of 5 positive (for $\mathrm{HCV}$ ) samples to check the inhibitory effects (if any) fotabler PCR. All the samples showed positive results after agarose gel electrophoresis (Fig. 1).

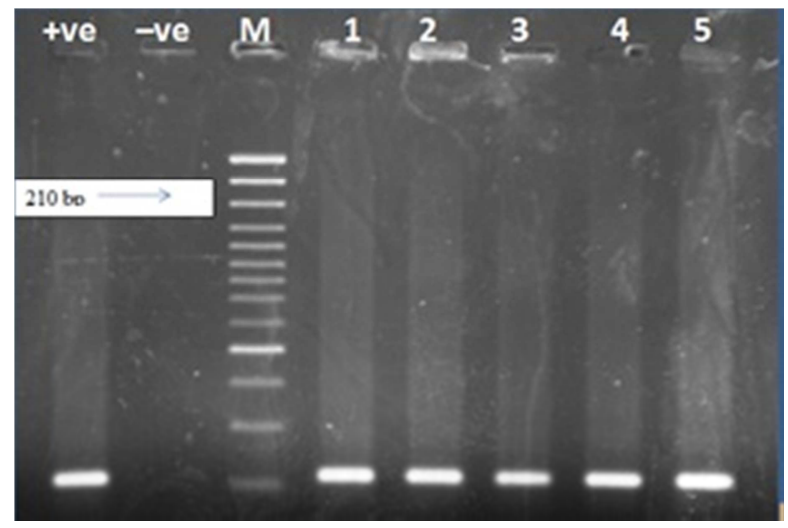

Fig. 1. Conventional PCR agarose gel picture of HCV positive samples mixed with ash of incinerated infectious waste, +ve control, -ve control, M (50bp marker), 1-5 samples.

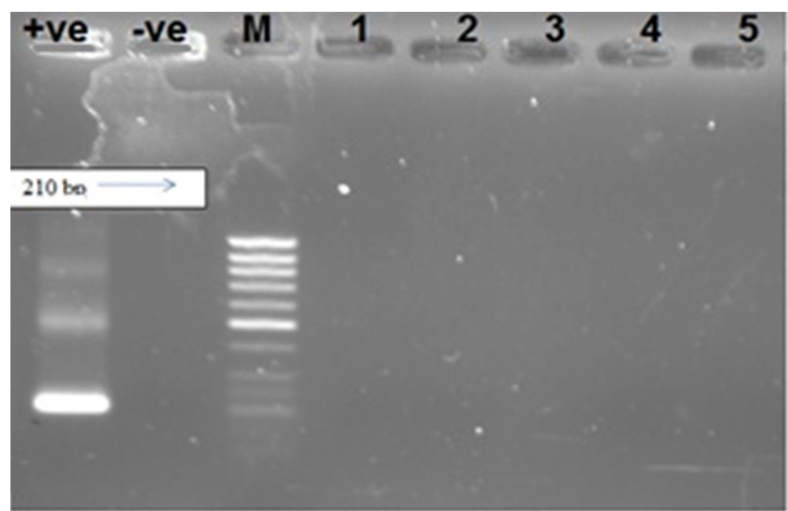

Fig. 2. Conventional PCR agarose gel picture of incinerated infectious waste ash mixed with Ultra-pure water for HCV conformation in ash, +ve control, -ve control, M (50bp marker), 1-5 samples.
Incinerated infectious waste ash was mixed with ultra-pure water to check the presence of HCV in ash. Results were negative (Fig. 2) which showed incineration killed the entire hepatitis $\mathrm{C}$ virus present in infectious waste.

\subsection{PCR Results for Hepatitis B}

Ash of incinerated infectious waste was mixed with blood serum of 5 positive (for HBV) samples. All the samples showed positive results after agarose gel electrophoresis (Fig. 3).

Incinerated infectious waste ash was mixed with ultra-pure water to check the presence of HBV in ash. Results were negative (Fig. 4) which showed incineration killed the entire hepatitis B virus present in infectious waste.

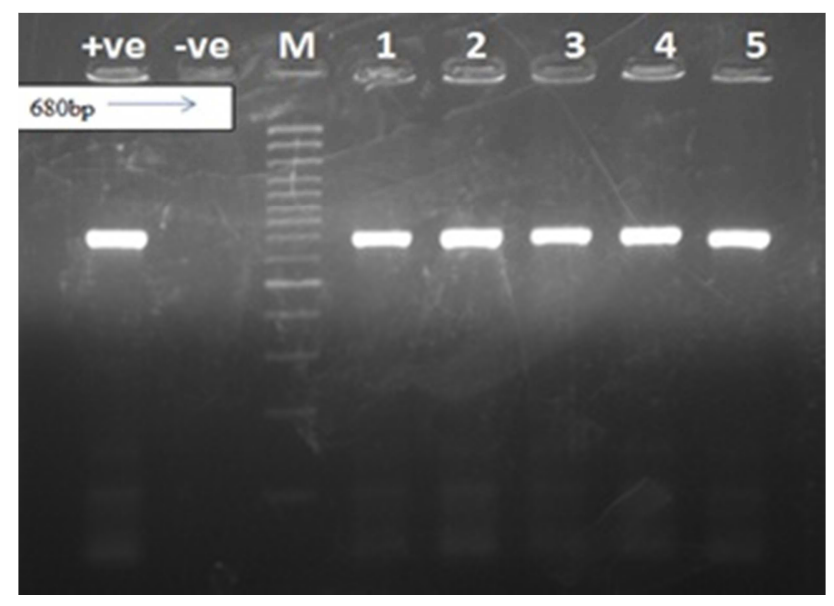

Fig. 3. Conventional PCR agarose gel picture of HBV positive samples mixed with ash of incinerated infectious waste, +ve control, -ve control, M (100bp marker), 1-5 samples.

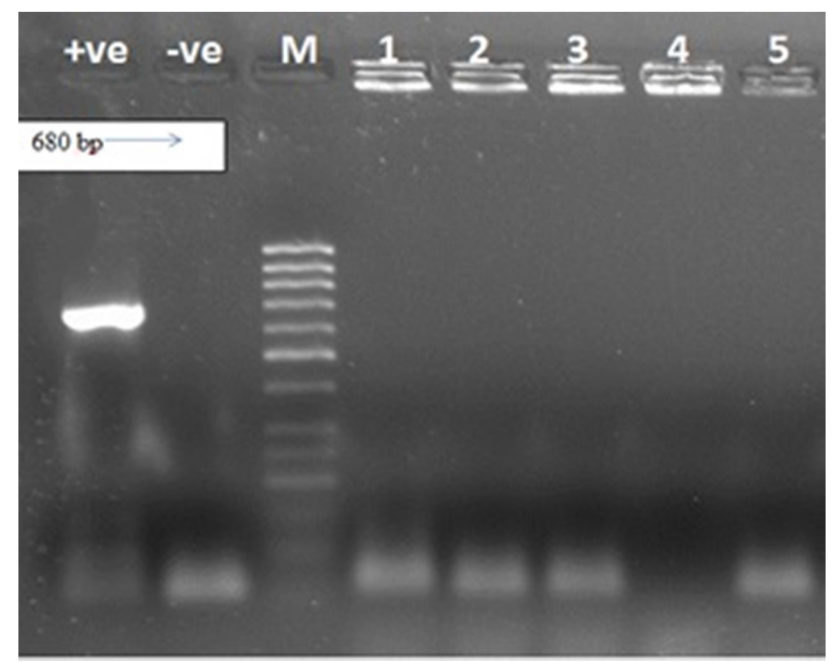

Fig. 4. Conventional PCR agarose gel picture of incinerated infectious waste ash mixed with Ultra pure water for HBV conformation in ash, +ve control, -ve control, $M$ (50bp marker), 1-5 samples.

\subsection{Radioactive Waste}

Radioactive waste at PINUM includes waste of $99 \mathrm{mTc}$ and I131. Waste of $\mathrm{I} 125$ results from diagnostic activities by RIA lab.I125 waste from RIA labs is exempted from any prior treatment before disposal by PNRA, so it was disposed 
off with infectious waste for incineration. 131I is used for thyroid and whole body scan and thyroid therapy. 99mTcis used for different scans e.g. heart, bone, and other scans of the organs of body. PNRA guidelines are to store waste of 131I for 6 months and 99mTC for 3 months to complete its decay process and bring its activity to background level which is not harmful for humans and environment. PINUM is the only center in town providing diagnostic and therapeutic facilities in nuclear medicine. As a result large numbers of patients visit PINUM for different kind of scans and radionuclide therapy. There was limited space for storage of radioactive waste in the hospital. To cope up with storage problem in this study proper segregation of radioactive was implemented. Radioactive waste was divided into two categories.

- Lose radioactive waste: gloves, swabs, tissue papers, syringes etc.

- Compact radioactive waste: glass vials of radio nuclides and needles.

Compact radioactive waste was stored for the exact period of time according to the guidelines by PNRA, as the activity in glass vials and needles remain for longer period of time and also they are not incinerated into ash.

Lose radioactive waste was isolated at the point of generation and was disposed after different time periods by incineration. Activity in waste was measured by survey mater before and after incineration and also in fumes during incineration.

Results showed that lose radioactive waste of $131 \mathrm{I}$ can be disposed after 4 months and of 99mTc after 2 months instead of 3 . Hence it will produce more space for radioactive waste storage and waste can be managed properly by applying better segregation practice. It also greatly reduces cost on management of waste and risk to human health and environment.

\subsection{Radiation Count on Infectious Waste Incineration with Time Limits}

\subsubsection{Radiation Count from Radioactive Waste of I131 on Weekly and Monthly Basis}

Radiation count rate from I131 waste was calculated by using radiation survey meter on weekly basis which included radiation counts before, during and after incineration of waste in the ash (Table 1). Only lose radioactive waste (gloves, swabs, tissue papers, syringes) was incinerated at weekly basis and not the compact radioactive waste (glass vials of radio nuclides and needles) as it contained higher activity and its disposal or incineration on weekly basis is not recommended. Radiation count scale was adjusted on $\mu \mathrm{Sv} / \mathrm{hr}$ weight of the radioactive waste was also done before incineration.

Table 1. Radiation count from radioactive waste of I131.

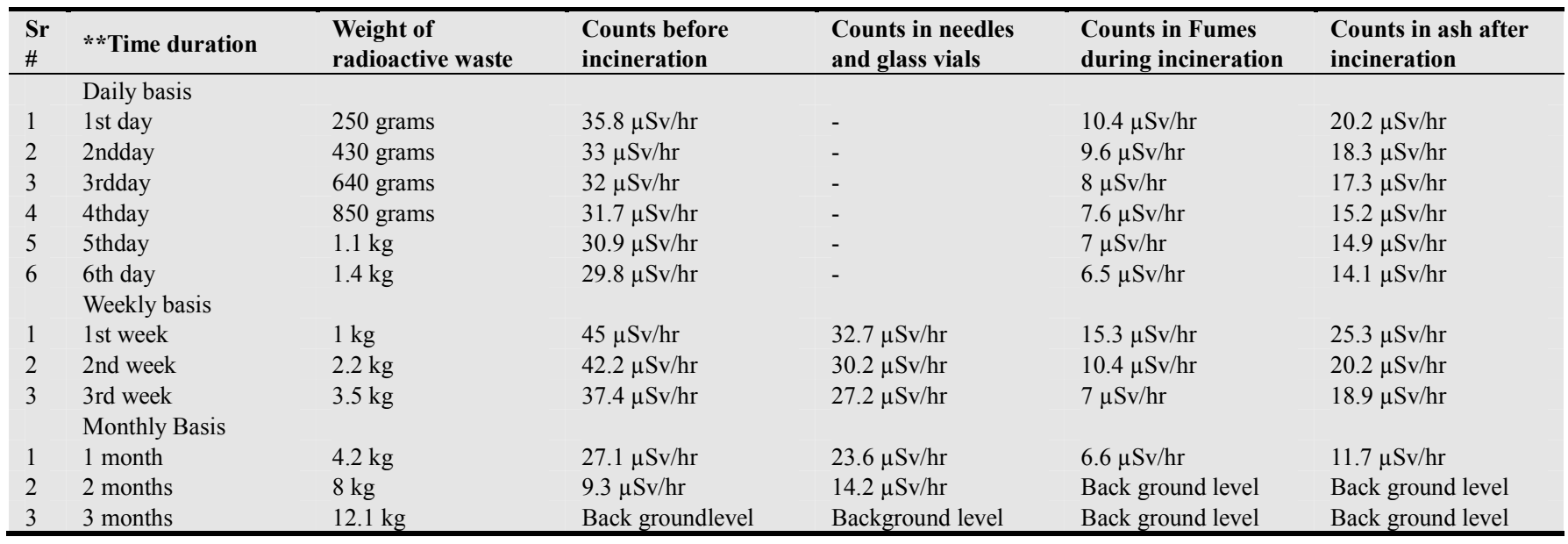

Table 2. Radiation count from radioactive waste of I131.

\begin{tabular}{|c|c|c|c|c|c|c|}
\hline $\mathrm{Sr} \#$ & **Time duration & $\begin{array}{l}\text { Weight of } \\
\text { radioactive waste }\end{array}$ & $\begin{array}{l}\text { Counts before } \\
\text { incineration }\end{array}$ & $\begin{array}{l}\text { Counts in needles } \\
\text { and glass vials }\end{array}$ & $\begin{array}{l}\text { Counts in Fumes } \\
\text { during incineration }\end{array}$ & $\begin{array}{l}\text { Counts in ash after } \\
\text { incineration }\end{array}$ \\
\hline & Weekly Basis & & & & & \\
\hline 1 & 1 week & 210 grams & $75 \mu \mathrm{Sv} / \mathrm{hr}$ & - & $10.3 \mu \mathrm{Sv} / \mathrm{hr}$ & $55.6 \mu \mathrm{Sv} / \mathrm{hr}$ \\
\hline 2 & 2 weeks & 390 grams & $73.1 \mu \mathrm{Sv} / \mathrm{hr}$ & - & $9.4 \mu \mathrm{Sv} / \mathrm{hr}$ & $53.8 \mu \mathrm{Sv} / \mathrm{hr}$ \\
\hline 3 & 3 weeks & 550 grams & $72.4 \mu \mathrm{Sv} / \mathrm{hr}$ & - & $9.5 \mu \mathrm{Sv} / \mathrm{hr}$ & $52.2 \mu \mathrm{Sv} / \mathrm{hr}$ \\
\hline 4 & $\begin{array}{l}4 \text { weeks } \\
\text { Monthly Basis }\end{array}$ & 800 grams & $70.3 \mu \mathrm{Sv} / \mathrm{hr}$ & - & $9 \mu \mathrm{Sv} / \mathrm{hr}$ & $50 \mu \mathrm{Sv} / \mathrm{hr}$ \\
\hline 1 & 2 months & $2 \mathrm{~kg}$ & $63.2 \mu \mathrm{Sv} / \mathrm{hr}$ & $50.3 \mu \mathrm{Sv} / \mathrm{hr}$ & $7.3 \mu \mathrm{Sv} / \mathrm{hr}$ & $47.1 \mu \mathrm{Sv} / \mathrm{hr}$ \\
\hline 2 & 3 months & $3.4 \mathrm{~kg}$ & $40.2 \mu \mathrm{Sv} / \mathrm{hr}$ & $39.5 \mu \mathrm{Sv} / \mathrm{hr}$ & $6 \mu \mathrm{Sv} / \mathrm{hr}$ & $30.1 \mu \mathrm{Sv} / \mathrm{hr}$ \\
\hline 3 & 4 months & $4.4 \mathrm{~kg}$ & $18.7 \mu \mathrm{Sv} / \mathrm{hr}$ & $27 \mu \mathrm{Sv} / \mathrm{hr}$ & Back ground level & $10.2 \mu \mathrm{Sv} / \mathrm{hr}$ \\
\hline 4 & 5 months & $5.2 \mathrm{~kg}$ & Back ground level & $9.3 \mu \mathrm{Sv} / \mathrm{hr}$ & Back ground level & Back ground level \\
\hline 5 & 6 months & $06 \mathrm{~kg}$ & Back ground level & Back ground level & Back ground level & Back ground level \\
\hline
\end{tabular}

Compact radioactive waste (glass vials of radio nuclides and needles) was also included in this study (Table 1). It was 
evident that if properly segregated lose radioactive waste (gloves, swabs, tissue papers, syringes) of I131 can be disposed after 4 months storage instead of prescribed 6 months and hence creating space for the storage of more compact radioactive waste.

\subsubsection{Radiation Count from Radioactive Waste of $99 m$ Tc on Daily / Weekly / Monthly Basis}

Radiation count of technetium 99mTc was calculated on daily, weekly and monthly basis (Table 2). Only lose radioactive waste of $99 \mathrm{mTc}$ was included as compact waste had high rate of radiation emission when treated on daily basis. Weight of the waste was done before treatment.

It was evident from results that if radioactive waste of $99 \mathrm{mTc}$ is properly segregated and stored it could be treated and disposed off after 2 months of storage instead of 3 months.

\section{Discussion}

Infectious waste management plan was prepared according to better waste management guidelines including proper segregation, storage, transport, treatment and final disposal. Results showed that incineration can be employed effectively in countries like Pakistan with economic issues who cannot afford expensive waste treatment costs of modern technology based practices like autoclaving etc.

The most prevalent cause of infections from health care waste is by needle prick injuries and by sharps that are contaminated with blood and other infectious body fluids. So it is recommended that used sharps, syringes and needles should be handled properly and not placed in polythene or plastic bags which can be easily punctured. To avoid airborne transmission of pathogens open and uncovered waste containers should not be used [16]. According to the WHO code of practices incineration of health care waste is the most commonly used and effective treatment option. During many incineration processes most of the waste is partially burned which is a serious health risk [17]. Improperly operated incinerators emit heavy metals and organic substances which are very harmful for human health and environment [17]. The dumping and disposal of health care waste to general waste dumping sites, present serious hazards to environment and human health by ground water and soil contamination as health care waste contain toxic and infectious elements [18]. Health care waste is $5-15$ times more toxic in nature than the general and domestic waste $[18,19]$. Most crucial element in hospital waste management is proper and safe packaging of hospital waste prior to final disposal or treatment. Proper packaging reduces the chances of contaminations to waste handlers and also minimize the harmful effects of waste on environment [12]. Substantial literature is present about the input of radioactive waste in the environment and ways to process these radioactive wastes [14]. However, little attention is paid towards the proper management of radioactive waste and its minimization which is produced from health care centre. Amount of radioactive waste is increasing as a result of increased diagnostic and therapeutic activities shifted towards nuclear medicine these days.

It should be ensured that the amount and volume of radioactive waste is kept to minimum achievable level and the waste is managed i.e. collected, stored, transported and disposed off according to the guidelines of regulatory body [18].

\section{Recommendations}

- Hospital waste either infectious or radioactive if segregated properly at the point of its generation, it greatly reduces the chances of infection to the staff and community and also less harmful to the environment.

- Frequent training programs for staff involved in handling and managing hospital waste and Public awareness symposiums and seminars should be conducted to minimize the risks of infection and for proper and effective waste management. It will help to create awareness among people about highly infectious diseases such as HBV, HCV and HIV.

- Policies and legislations are very necessary for proper hospital waste management. Implementation of these defined polices and financial assistance for implementing waste management technologies is very important for effective waste management

\section{Acknowledgement}

The authors are highly thankful to the PINUM (Punjab Institute of Nuclear Medicine) hospital Faisalabad for all experimental assistance and lab analysis.

\section{Abbreviations}

PINUM (Punjab institute of Nuclear Medicine), HCV (Hepatitis C virus), HBV (Hepatitis B virus), PCR (polymerase chain reaction), TB (Tuberculosis), I131 (Iodine-131), 99mTc (Technetium-99m), $\mu \mathrm{Sv} \quad / \mathrm{hr}$ (micro-Sieverts per hour, a standard unit of measurement for radioactivity), PNRA (Pakistan nuclear regulatory authority).

\section{References}

[1] S. R. Dodhy, "Solid Waste and pollution-Silent killer," J Pak Textile, vol. 55, pp. 42-44, 2006.

[2] J. L. Morrison, "The contagious hospital," On the Horizon, vol. 1, pp.11-12, 1992.

[3] N. Al-Mutair, M. Terro, A. L. Al-Khaleefi, "Effect of recycling hospital ash on the compression properties of concrete: statistical assessment and predicating model," Building Environment, vol. 39, pp. 557-566, 2004.

[4] Sabiha-Javied, M. Tufail, K. Sofia, "Heavy metal pollution from medical waste incineration at Islamabad and Rawalpindi," J Microchemical. Pakistan, vol. 90, pp. 77-81, 2008. 
[5] M. L. Johannessen, M. Dijkman, C. Bartone, D. Hanrahan, M. G. Boyer, C. Chandra, Health Care Waste Management Guidance Note: Health Nutrition and Population (HNP) Discussion, 2000.

[6] C. A. Smith, "Managing Pharmaceutical Waste-what pharmacist should know," J. Pharm. Soc. Wisconsin, pp. 17-22, 2002.

[7] National Institute for Occupational Safety and Health (NIOSH).Preventing Occupational Exposure to Antineoplastic and other Hazardous Drugs in Healthcare Settings, 2004.

[8] M. Askarian, M. Vakili, G, Kabir, "A total quality management approach to healthcare waste management in Namazi Hospital," Waste Mangement. Iran, vol. 30(11), pp. 2321-2362, 2010.

[9] J. I. Blenkharn, "Lowering standards of clinical waste management: do the hazardous waste regulations conflict with the CDC's universal/standard precautions?," J. Hosp. Infect, vol. 62(4), pp. 467-472, 2006 a.

[10] A. Pruss, E. Giroult, P. Rushbrook, "Safe Management of Waste from Health Care Acivities," World Health Organization, Geneva, Switzerland, 1999.

[11] A. Abdulla, M. Gomei, D. Hyrenbach, G. Notarbartolo-di-Sciara," Challenges facing a network of representative marine protected areas in the Mediterranean: prioritizing protection of underrepresented habitat," ICES Journal of Marine Science, vol. 66, pp. 22-28, 2008.

[12] Ministry of environment Pakistan, "Hospital waste management rule," The Gazette of Pakistan, Ministry of environment notification, 2005.
[13] P. Klangsin, A. K. Harding," Medical waste treatment and disposal methods used by hospitals in Oregon, Washington and Idaho," J Air Waste Manag Assoc, vol.48, pp.516-26, 1998.

[14] Y. A. Levendis, A. Atal, J. Carlson," PAH and soot emissions from combustion of coal and waste tires in fixed beds," Comb. Sci. Technol, vol. 134, pp. 407-431, 1998.

[15] Operational limits," Training workshop on Radiation Safety in Nuclear Medicine and RSO Certification Examination," Murthy BKS, BARC. Mumbai, pp. 6.1-6.6, 2000.

[16] WHO, 2000.In: Rushbrook, P., Chandra, C., Gayton, S., (Eds.), starting health-care waste management in medical institutions. Health-care waste practical information series, No. 1. WHO regional office for Europe, European centre for environment and health, Copenhagen. Samajh ni lagi.

[17] M. C. Agramunt, A. Domingo, J. L. Domingo, J. Corbella, "Monitoring internal exposure to metals and organic substances in workers at a hazardous waste incinerator after 3 years of operation," Toxicology letters, vol.146, pp.83-91, 2003.

[18] M. Tsakona, E. Anagnostopoulou, E. Gidarakos, "Hospital waste management and toxicity evaluation: A case study," Waste management, vol. 27(7), pp. 912-920, 2007.

[19] R. Mohee, "Medical waste characterization in health care institutions in Mauritius," Waste management, vol. 25, pp. 575-581, 2005. 